\title{
Optimasi Persediaan Pupuk Non-Subsidi Menggunakan Programa Dinamis Model Inventory (UD. Barokah)
}

\author{
Reynaldy Teja Kusumah ${ }^{1}$, Anita Ilmaniati ${ }^{2}$ \\ 1,2 Teknik Industri Universitas Suryakancana \\ Jl. Pasir Gede Raya, Cianjur 43216 \\ ${ }^{1}$ reynaldyteja69@gmail.com, ${ }^{2}$ anitailmaniati@unsur.ac.id
}

Dikirimkan: 11, 2019. Diterima: 11, 2019. Dipublikasikan: 12, 2019

\begin{abstract}
Fertilizer is one component that plays an important role in increasing agricultural production and productivity. Effective and efficient fertilizer distribution is the main key in sales optimization. Problems often arise in the distribution of fertilizers, namely supplies that are not in accordance with the amount of demand. UD Barokah is one of the official retailers of subsidized and non-subsidized fertilizers in Cianjur Regency which often experiences problems with stockpiling of non-subsidized fertilizer stocks. The average buildup at UD Barokah reached $4213 \mathrm{~kg}$ of non-subsidized fertilizer per month in 2017. The buildup became an additional cost burden for UD Barokah. This study aims to determine the optimal amount of non-subsidized fertilizer supply and the optimal cost for non-subsidized fertilizer supply. The method used in this research is demand forecasting method with linear regression and dynamic programming to determine inventory. Based on the results of the study, it was found that the regulation of non-subsidized fertilizer supplies in 2018-2019 at UD. Barokah ranges between 18,000 kg -26,000 per month with a total cost of Rp.7,741,134,625.
\end{abstract}

Keywords - Optimization, dynamic programming, demand forecasting

\begin{abstract}
Abstrak- Pupuk merupakan salah satu komponen yang berperan penting dalam peningkatan produksi dan produktivitas pertanian. Penyaluran pupuk yang efektif dan efisien menjadi kunci utama dalam optimasi penjualan. Sering kali timbul permasalahan dalam penyaluran pupuk yaitu persediaan yang tidak sesuai dengan jumlah permintaan. UD Barokah merupakan salah satu pengecer resmi pupuk bersubsidi maupun non-subsidi di Kabupaten Cianjur yang sering mengalami permasalahan penumpukan stok pupuk non-subsidi. Rata-rata penumpukan pada UD Barokah mencapai $4213 \mathrm{~kg}$ pupuk non-subsidi per-bulan dalam tahun 2017. Penumpukan tersebut menjadi beban biaya tambahan bagi UD Barokah. Penelitian ini bertujuan untuk menentukan jumlah persediaan pupuk non-subsidi yang optimal dan biaya optimal untuk persediaan pupuk non-subsidi. Metode yang digunakan dalam penelitian ini adalah metode peramalan permintaan dengan regresi linier dan programa dinamis untuk menentukan persediaan. Berdasarkan hasil penelitian, didapatkan bahwa pengaturan persediaan pupuk non-subsidi pada tahun 2018-2019 di UD. Barokah berikisar antara $18.000 \mathrm{~kg}$ 26.000 per bulan dengan total biaya adalah Rp.7.741.134.625.
\end{abstract}

Kata Kunci-Optimasi, programa dinamis, peramalan permintaan

\section{PENDAHULUAN}

Indonesia dikenal sebagai negara agraris dimana pertanian merupakan salah satu penggerak ekonomi nasional. Pupuk merupakan salah satu komponen masukan (input) yang berperan penting dalam peningkatan produksi dan produktivitas pertanian. Pupuk dapat membantu meningkatkan kesuburan tanah sehingga produksi tanaman bisa berjalan baik sesuai dengan waktu dan kualitas tanaman yang diinginkan. Karena perannya tersebut, pupuk menjadi komoditas dagang dengan potensi penjualan yang cukup tinggi.
Penyaluran pupuk yang efektif dan efisien menjadi kunci utama dalam optimasi penjualan, namun sering kali timbul permasalahan dalam penyaluran pupuk yaitu permasalahan dalam persediaan barang. Dalam kasus nyata, sering terjadi peningkatan permintaan yang tidak sesuai dengan bahan sehingga permintaan pun tidak dapat dipenuhi dengan baik. Hal tersebut menyebabkan keuntungan yang diperoleh perusahaan tidak sesuai dengan harapan yang diinginkan. Persediaan adalah sumber daya menganggur (idle resources) yang menunggu proses lebih lanjut. Yang dimaksud dengan proses lebih lanjut adalah 
berupa kegiatan produksi pada sistem manufaktur, kegiatan pemasaran pada sistem distribusi ataupun kegiatan konsumsi pangan pada sistem rumah tangga [1]

UD Barokah merupakan salah satu pengecer resmi penjual pupuk bersubsidi maupun non subsidi serta alat-alat pertanian lainnya. Berdasarkan hasil observasi yang dilakukan, UD Barokah kesulitan dalam menentukan jumlah persediaan pupuk non-subsidi yang optimal agar tidak terjadi penumpukan di gudang. UD Barokah pada tahun 2017 dapat dilihat dari tabel 1. Dalam kondisi aktualnya, di UD Barokah ini sering kali terjadi penumpukan pupuk non-subsidi. Penumpukan tersebut menjadi suatu beban biaya tambahan, sehingga mengurangi keuntungan UD Barokah. Penumpukan yang tejadi di UD Barokah dapat diketahui berdasarkan data sisa pupuk nonsubsidi per bulan di tahun 2017 pada Tabel I dan data perbandingan penjualan dengan persediaan pupuk tahun 2017 pada gambar 1 .

TABEL I

REKAPITUlasi PENUMPUKAN PERSEDIAAN PUPUK UD. BAROKAH TAHUN 2017

\begin{tabular}{|l|c|c|}
\multicolumn{1}{c}{ Bulan } & $\begin{array}{c}\text { Jumlah Sisa } \\
(\mathrm{kg})\end{array}$ & \% Sisa \\
\hline Januari & 1967 & $9.74 \%$ \\
\hline Februari & 3401 & $15.38 \%$ \\
\hline Maret & 4359 & $18.47 \%$ \\
\hline April & 5007 & $20.47 \%$ \\
\hline Mei & 3306 & $14.55 \%$ \\
\hline Juni & 4597 & $19.64 \%$ \\
\hline Juli & 5008 & $20.57 \%$ \\
\hline Agustus & 5231 & $20.82 \%$ \\
\hline September & 5712 & $22.46 \%$ \\
\hline Oktober & 5476 & $21.53 \%$ \\
\hline November & 3455 & $14.18 \%$ \\
\hline Desember & 3047 & $12.88 \%$ \\
\hline
\end{tabular}

Grafik perbandingan penjualan dengan persediaan pupuk non-subsidi pada Gambar 1 menunjukan bahwa penjualan dengan persediaan pupuk non-subsidi tidak balance. Artinya UD Barokah ini belum mencapai keuntungan yang optimal, karena masih sering terjadi penumpukan bahan yang rata-rata penumpukannya mencapai $4213 \mathrm{~kg}$ pupuk non-subsidi per-bulan dalam tahun 2017. Dari penumpukan tersebut tentunya akan menimbulkan kerugian bagi UD Barokah. Estimasi kerugian yang akan ditanggung oleh UD Barokah yaitu sekitar Rp.44.939.017 per-bulan dari semua jenis pupuk non-subsidi yang tidak terjual.

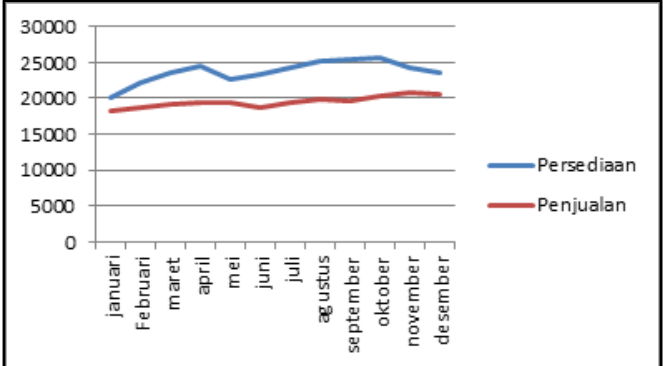

Gambar.1 Grafik Perbandingan Penjualan dengan Persediaan Pupuk Non-subsidi

Penelitian ini bertujuan untuk mengetahui penentuan jumlah persediaan pupuk non-subsidi yang optimal dan juga mengetahui biaya persediaan pupuk non-subsidi di UD Barokah setelah diterapkannya jumlah persediaan pupuk non-subsidi yang optimal. Beberapa batasan yang digunakan dalam penelitian yaitu harga pupuk non-subsidi pada tahun 2018-2019 diasumsikan tetap, dan asumsi bahwa penjualan pupuk subsidi tidak berpengaruh terhadap naik turunnya penjulan pupuk non-subsidi.

\section{Metodologi Penelitian}

\subsection{Kerangka Penelitian}

Penelitian ini menerapkan metode ilmiah secara umum dengan langkah-langkah seperti yang digambarkan pada Gambar 2.

\subsection{Model Penelitian}

Metode yang digunakan pada penelitian ini adalah programa dinamis, sehingga model penelitian yang dibentuk adalah model matematis rekursif. Program dinamis adalah teknik matematika yang digunakan untuk membuat suatu rangkaian keputusan yang saling terkait [2]. Prosedur pemecahan persoalan dalam program dinamik dilakukan secara rekursif. Artinya, bahwa setiap kali diambil keputusan, diperhatikan keadaan yang dihasilkan oleh keputusan sebelumnya [3].

Perhitungan programa dinamis pada penelitian ini menggunakan rekrusif maju yang dimulai dari tahap awal yaitu bulan Januari 2018 sampai dengan tahap 24 bulan Desember 2019. Urutan perencanaan persediaan pupuk non-subsidi dengan program dinamik ditunjukkan pada tahapan berikut :

1. Dekomposisi, permasalahan perencanaan persediaan pupuk nonsubsidi dipecah menjadi beberapa sub masalah. Dalam penelitian ini hubungan antar tahap dinyatakan dengan rekrusif maju pada tahap 1 sampai tahap 24 artinya persediaan bulan Januari tahun 2018 sampai dengan bulan Desember tahun 2019. 


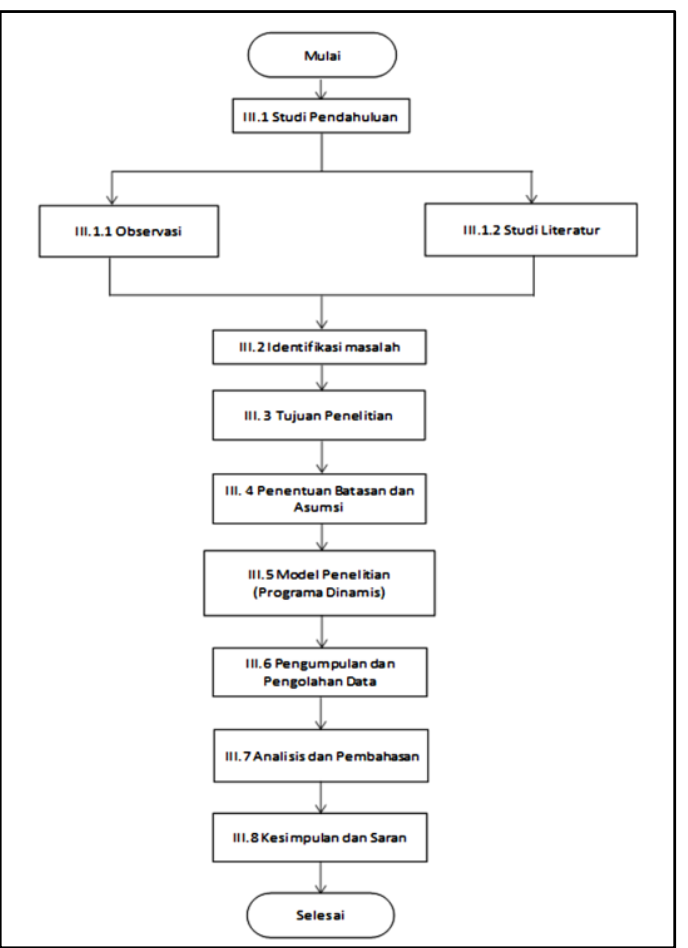

Gambar.2 Tahapan penelitian

2. Menentukan variable masukan atau state pada tiap tahapan. Dalam penelitian ini adalah hasil peramalan, sisa persediaan pupuk yang tidak terjual pada bulan sebelumnya, dan biaya simpan per-kilo gram pupuk.

3. Menentukan variable keputusan. Dalam penelitian ini adalah menentukan jumlah persediaan pupuk berdasarkan peramalan.

4. Mengidentifikasi kendala-kendala. Dalam penelitian ini kendala yang ada di perusahaan yaitu kapasitas gudang dan jumlah persediaan maksimum yang diizinkan.

5. Menetapkan fungsi tujuan:

$f_{n}\left(X_{n}\right)=\operatorname{Min}\left\{h_{n}\left(x_{n}+z_{n}-D_{n}\right)+f_{i-1}\left(x_{n}+z_{n}-D_{n}\right)\right\}$

Keterangan :

$f_{n}\left(X_{n}\right)=$ biaya persediaan minimum pupuk non-subsidi pada tahap $n$

$D_{n}=$ banyaknya permintaan pada tahap $n$

$x_{n}=$ persediaan awal pada periode $n$

(sisa)

$z_{n}=$ jumlah yang dipesan

$h_{n}=$ biaya persediaan per kilo gram item

6. Penyelesaian model dengan Programa Dinamis dapat dilihat pada gambar 3 berikut ini.

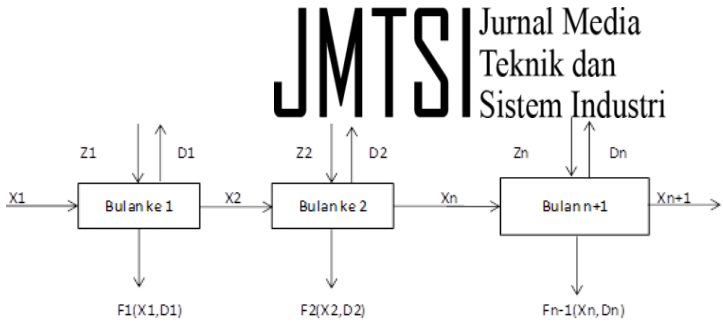

Gambar.3 Model Penelitian

\section{HASIL PENELITIAN}

\subsection{Hasil Peramalan}

Dalam penelitian ini untuk perbandingan peramalan dilakukan dengan 2 metode yaitu Peramalan dengan Regresi Linier dan Peramalan dengan Double Exponential Smoothing Dua Parameter dari Holt. Aktivitas peramalan merupakan suatu fungsi bisnis yang berusaha memperkirakan penjualan dan penggunaan suatu produk sehingga produk-produk itu dapat dibuat dalam kuantitas yang tepat [4]. Berikut adalah hasil perbandingan kedua metode peramalan yang terlihat pada Tabel.2 berikut.

TABEL II

PERBANDINGAN KEDUA METOde PERAMALAN



Berdasarkan Tabel II di atas dapat dilihat bahwa peramalan dengan metode Regresi Linier mempunyai jumlah nilai Error ME, MAE, MSE, dan $S D E$ yang relatif lebih kecil dibandingkan dengan metode Double Eksponensial Smoothing Dua Parameter dari Holt. Maka untuk perhitungan selanjutnya didasarkan pada hasil peramalan Regresi Linier.

\subsection{Pemograman Dinamis}

Metode pemograman dinamis memerlukan data-data input sebagai berikut:

- $\quad$ Kapasitas maksimal gudang $=40.000 \mathrm{~kg}$ 
- $\quad$ Biaya beli/unit (c) $=14.000 \mathrm{rupiah} / \mathrm{kg}$ Untuk biaya beli karena setiap item berbeda-beda harga, maka dalam pemrograman dinamis ini di asumsikan dengan rata-rata harga setiap item pupuk non-subsidi yaitu sebesar 14.000 rupiah.

- $\quad$ Biaya simpan/unit (h) $=665$ rupiah $/ \mathrm{kg}$

- Periode keputusan $(n)=24$ bulan

- Jumlah barang dipesan periode- $\mathrm{i}=\mathrm{zi}$

- Jumlah permintaan periode- $\mathrm{i}=\mathrm{Di}$

- $\quad$ Persediaan pada awal periode $\mathrm{i}=\mathrm{xi}$

- $\quad$ Persediaan pada akhir periode $i+1=x i+1$

Persamaan rekursif untuk tahap basis dan nonbasis:

1.) Persamaan basis:

$$
f_{1}\left(x_{2}\right)=\min _{z_{i}=D_{i}+x_{2}-x_{1}}\left\{c\left(z_{1}\right)+h x_{2}\right\}
$$

2.) Persamaan non-basis:

$$
\begin{aligned}
& f_{i}\left(x_{i+1}\right)=\min _{0 \leq z_{i} \leq D_{i}+x_{i+1}}\left\{c\left(z_{i}\right)+h x_{i+1}+f_{i-1}\left(x_{i+1}+D_{i}-z_{i}\right)\right\} \\
& i=1,2,3, \ldots, n
\end{aligned}
$$

Asumsi yang digunakan dalam perhitungan diantaranya:

1. Pembelian produk harus per $2000 \mathrm{~kg}$, karena 1 truk engkel kecil roda 4 mampu memuat maksimal $2000 \mathrm{~kg}$ pupuk (pengecualian apabila zi $\leq 250 \mathrm{Di}$, maka Di harus terpenuhi).

2. Persediaan dan permintaan produk selalu dibulatkan ke atas kelipatan $25 \mathrm{~kg}$

3. Persediaan pada tahap $0(x 1)=3047 \mathrm{~kg}$ (dibulatkan menjadi $3050 \mathrm{~kg}$ )

Berdasarkan data input tersebut dapat disusun data alternatif persediaan dan pembelian bahan baku per-periode seperti pada Lampiran 1.

Contoh perhitungan rekursif maju tahap 1 dan tahap 2 adalah sebagai berikut (tabel perhitungan terdapat pada Lampiran 2 ):

1) Contoh perhitungan tahap $1(n=1)$

$\mathrm{x} 2=225, \mathrm{z} 1=18.000$

$f_{1}\left(x_{2}\right)=\min _{z_{i}=D_{i}+x_{2}-x_{1}}\left\{c\left(z_{1}\right)+h x_{2}\right\}$

$f_{1}\left(x_{2}\right)=\min \{14.000(18.000)+149.625\}$

$f_{1}\left(x_{2}\right)=\min \{252.000 .000+149.625\}$

$f_{1}\left(x_{2}\right)=252.149 .625$

2) Contoh perhitungan tahap $2(n=2)$ $\mathrm{x} 3=1200, \mathrm{z} 2=22.000$

$f_{2}\left(x_{3}\right)=\min \left\{c\left(z_{2}\right)+h x_{3}+f_{1}\left(x_{3}+D_{2}-z\right.\right.$

$f_{2}\left(x_{3}\right)=\min \left\{14.000(22.000)+798.000+f_{1}(1.200+21.025-22.00\right.$

$f_{2}\left(x_{3}\right)=\min \left\{308.000 .000+798.000+f_{1}(22 s\right.$

$f_{2}\left(x_{3}\right)=\min \{308.798 .000+252.149 .625\}$

$f_{2}\left(x_{3}\right)=560.947 .625$

Berdasarkan perhitungan rekursif maju, didapatkan hasil pembelian produk dengan pemograman dinamis adalah seperti pada Tabel III dan Tabel IV.

TABEL III

REKAPITULASI HASIL PEMBELIAN PRODUK 2018-2019 DENGAN PEMOGRAMAN DINAMIS

\begin{tabular}{|c|c|c|c|c|c|c|c|}
\hline Bulan & $\begin{array}{c}\text { Pupuk Mutiara } \\
\text { NPK 16-16-16 } \\
25 \text { kg }\end{array}$ & $\begin{array}{c}\text { Pupuk } \\
\text { Mutiara } \\
\text { NPK 16-16- } \\
1650 \mathrm{~kg}\end{array}$ & $\begin{array}{c}\text { Pupuk } \\
\text { Merokecalnit } \\
\mathbf{2 5} \text { kg }\end{array}$ & $\begin{array}{c}\text { Pupuk } \\
\text { Merokesop } \\
\mathbf{2 5} \text { kg }\end{array}$ & $\begin{array}{c}\text { Pupuk } \\
\text { Merokekali } \\
\text { nitra 25 kg }\end{array}$ & $\begin{array}{c}\text { Pupuk Meroke } \\
\text { nitrafos 25 kg }\end{array}$ & Jumlah Pembelian \\
\hline Jan-18 & 1650 & 15350 & 400 & 270 & 150 & 200 & $18000 \mathrm{~kg}$ \\
\hline Feb-18 & 2025 & 18700 & 500 & 325 & 200 & 250 & $22000 \mathrm{~kg}$ \\
\hline Mar-18 & 1850 & 17025 & 425 & 300 & 200 & 225 & $20025 \mathrm{~kg}$ \\
\hline Apr-18 & 2025 & 18700 & 500 & 325 & 200 & 250 & $22000 \mathrm{~kg}$ \\
\hline Mei-18 & 2025 & 18700 & 500 & 325 & 200 & 250 & $22000 \mathrm{~kg}$ \\
\hline Jun-18 & 2025 & 18700 & 500 & 325 & 200 & 250 & $22000 \mathrm{~kg}$ \\
\hline Jul-18 & 2025 & 18700 & 500 & 325 & 200 & 250 & $22000 \mathrm{~kg}$ \\
\hline Agu-18 & 2025 & 18700 & 500 & 325 & 200 & 250 & $22000 \mathrm{~kg}$ \\
\hline Sep-18 & 2025 & 18700 & 500 & 325 & 200 & 250 & $22000 \mathrm{~kg}$ \\
\hline Okt-18 & 2025 & 18700 & 500 & 325 & 200 & 250 & $22000 \mathrm{~kg}$ \\
\hline Nov-18 & 2200 & 20400 & 525 & 360 & 225 & 300 & $24000 \mathrm{~kg}$ \\
\hline Des-18 & 2025 & 18700 & 500 & 325 & 200 & 250 & $22000 \mathrm{~kg}$ \\
\hline Jan-19 & 2200 & 20400 & 525 & 360 & 225 & 300 & $24000 \mathrm{~kg}$ \\
\hline Feb-19 & 2200 & 20400 & 525 & 360 & 225 & 300 & $24000 \mathrm{~kg}$ \\
\hline Mar-19 & 2025 & 18700 & 500 & 325 & 200 & 250 & $22000 \mathrm{~kg}$ \\
\hline Apr-19 & 2025 & 18700 & 500 & 325 & 200 & 250 & $22000 \mathrm{~kg}$ \\
\hline Mei-19 & 2200 & 20400 & 525 & 360 & 225 & 300 & $24000 \mathrm{~kg}$ \\
\hline Jun-19 & 2200 & 20400 & 525 & 360 & 225 & 300 & $24000 \mathrm{~kg}$ \\
\hline Jul-19 & 2400 & 22125 & 575 & 390 & 250 & 275 & $26000 \mathrm{~kg}$ \\
\hline Agu-19 & 2200 & 20400 & 525 & 360 & 225 & 300 & $24000 \mathrm{~kg}$ \\
\hline Sep-19 & 2200 & 20400 & 525 & 360 & 225 & 300 & $24000 \mathrm{~kg}$ \\
\hline Okt-19 & 2400 & 22125 & 575 & 390 & 250 & 275 & $26000 \mathrm{~kg}$ \\
\hline Nov-19 & 2200 & 20400 & 525 & 360 & 225 & 300 & $24000 \mathrm{~kg}$ \\
\hline Des-19 & 2400 & 22125 & 575 & 390 & 250 & 275 & $26000 \mathrm{~kg}$ \\
\hline
\end{tabular}

TABEL IV

RESUME DATA HASIL PERHITUNGAN PROGRAMA DiNAMIS

\begin{tabular}{|c|c|c|c|c|}
\hline Bulan & Jumlah Pembelian & Permintaan & Sisa & Total Biaya \\
\hline Jan-18 & $18000 \mathrm{~kg}$ & $20825 \mathrm{~kg}$ & $225 \mathrm{~kg}$ & 252.149 .625 \\
\hline Feb-18 & $22000 \mathrm{~kg}$ & $21025 \mathrm{~kg}$ & $1200 \mathrm{~kg}$ & 560.947 .625 \\
\hline Mar-18 & $20025 \mathrm{~kg}$ & $21225 \mathrm{~kg}$ & 0 & 841.297 .625 \\
\hline Apr-18 & $22000 \mathrm{~kg}$ & $21425 \mathrm{~kg}$ & $575 \mathrm{~kg}$ & 1.149 .680 .000 \\
\hline Mei-18 & $22000 \mathrm{~kg}$ & $21625 \mathrm{~kg}$ & $950 \mathrm{~kg}$ & 1.458 .311 .750 \\
\hline Jun-18 & $22000 \mathrm{~kg}$ & $21825 \mathrm{~kg}$ & $1125 \mathrm{~kg}$ & 1.767 .059 .875 \\
\hline Jul-18 & $22000 \mathrm{~kg}$ & $22025 \mathrm{~kg}$ & $1100 \mathrm{~kg}$ & 2.075 .791 .375 \\
\hline Agu-18 & $22000 \mathrm{~kg}$ & $22200 \mathrm{~kg}$ & $900 \mathrm{~kg}$ & 2.384 .389 .875 \\
\hline Sep-18 & $22000 \mathrm{~kg}$ & $22400 \mathrm{~kg}$ & $500 \mathrm{~kg}$ & 2.692 .722 .375 \\
\hline Okt-18 & $22100 \mathrm{~kg}$ & $22600 \mathrm{~kg}$ & 0 & 3.002 .052 .375 \\
\hline Nov-18 & $24000 \mathrm{~kg}$ & $22800 \mathrm{~kg}$ & $1200 \mathrm{~kg}$ & 3.338 .850 .375 \\
\hline Des-18 & $22000 \mathrm{~kg}$ & $23000 \mathrm{~kg}$ & $200 \mathrm{~kg}$ & 3.646 .983 .375 \\
\hline Jan-19 & $24000 \mathrm{~kg}$ & $23200 \mathrm{~kg}$ & $1000 \mathrm{~kg}$ & 3.983 .648 .375 \\
\hline Feb-19 & $24000 \mathrm{~kg}$ & $23400 \mathrm{~kg}$ & $1600 \mathrm{~kg}$ & 4.320 .712 .375 \\
\hline Mar-19 & $22000 \mathrm{~kg}$ & $23575 \mathrm{~kg}$ & $25 \mathrm{~kg}$ & 4.628 .729 .000 \\
\hline Apr-19 & $22000 \mathrm{~kg}$ & $23775 \mathrm{~kg}$ & $250 \mathrm{~kg}$ & 4.964 .895 .250 \\
\hline Mei-19 & $24000 \mathrm{~kg}$ & $23975 \mathrm{~kg}$ & $275 \mathrm{~kg}$ & 5.301 .078 .125 \\
\hline Jun-19 & $24000 \mathrm{~kg}$ & $24175 \mathrm{~kg}$ & $100 \mathrm{~kg}$ & 5.637 .144 .625 \\
\hline Jul-19 & $26000 \mathrm{~kg}$ & $24375 \mathrm{~kg}$ & $1725 \mathrm{~kg}$ & 6.002 .291 .750 \\
\hline Agu-19 & $24000 \mathrm{~kg}$ & $24575 \mathrm{~kg}$ & $1150 \mathrm{~kg}$ & 6.339 .056 .500 \\
\hline Sep-19 & $24000 \mathrm{~kg}$ & $24775 \mathrm{~kg}$ & $375 \mathrm{~kg}$ & 6.675 .305 .875 \\
\hline Okt-19 & $26000 \mathrm{~kg}$ & $24975 \mathrm{~kg}$ & $1400 \mathrm{~kg}$ & 7.040 .236 .875 \\
\hline Nov-19 & $24000 \mathrm{~kg}$ & $25150 \mathrm{~kg}$ & $350 \mathrm{~kg}$ & 7.376 .469 .625 \\
\hline Des-19 & $26000 \mathrm{~kg}$ & $25350 \mathrm{~kg}$ & $1000 \mathrm{~kg}$ & 7.741 .134 .625 \\
\hline & & & &
\end{tabular}

\subsection{Analisis Hasil Pemograman Dinamis}

Hasil pembelian pupuk non-subsidi peritem dapat dilihat dari tabe IV.43 dengan pembagian persentase dapat dilihat pada tabel IV.17. Sehingga terlihat berapa jumlah yang harus dipesan per-item pupuk non-subsidi untuk tahun 2018-2019. Dari tabel IV.43 dapat disimpulkan bahwa dengan pembelian perbulan $18.000 \mathrm{~kg}$ maka pembagian pembeliannya yaitu $1.650 \mathrm{~kg}$ untuk pupuk Mutiara NPK 16-16-16 25 kg, $15.350 \mathrm{~kg}$ untuk pupuk Mutiara NPK 16-16-16 $50 \mathrm{~kg}, 400 \mathrm{~kg}$ untuk pupuk merokecalnit $25 \mathrm{~kg}, 270 \mathrm{~kg}$ untuk pupuk merokesop $25 \mathrm{~kg}, 150 \mathrm{~kg}$ untuk pupuk merokekalinitra $25 \mathrm{~kg}$, dan $200 \mathrm{~kg}$ untuk pupuk merokenitrafos $25 \mathrm{~kg}$. Pada pembelian 6 jenis pupuk tersebut, pembelian di bulatkan keatas dan ke bawah di kondisikan berdasarkan hasil 
pembagian persentasenya. Begitupun dengan pembelian $20.000 \mathrm{~kg}, 22.000 \mathrm{~kg}, 24.000 \mathrm{~kg}$ dan $26.000 \mathrm{~kg}$ pembagian pembelian pupuk peritem disesuaikan dengan persentase yang sama dan jumlahnya di bulatkan ke atas dan ke bawah di kondisikan berdasarkan hasil pembagian persentasenya.

\section{KESIMPULAN}

Hasil dari penelitian yang telah dilakukan, dapat ditarik beberapa kesimpulan, diantaranya yaitu:

1. Penentuan jumlah persediaan pupuk nonsubsidi yang optimal adalah $18.000 \mathrm{~kg}$ pada bulan januari 2018, $22.000 \mathrm{~kg}$ untuk bulan Februari 2018, 20.025 kg untuk bulan Maret 2018, 22. $000 \mathrm{~kg}$ untuk bulan April 2018Oktober 2018, 24.000 kg untuk bulan November 2018, 22.000 kg untuk bulan Desember 2018, 24.000 kg untuk bulan Januari dan Februari 2019, $22.000 \mathrm{~kg}$ untuk bulan Maret dan April 2019, $24.000 \mathrm{~kg}$ untuk bulan Mei dan Juni 2019, $26.000 \mathrm{~kg}$ untuk bulan Juli 2019, $24.000 \mathrm{~kg}$ untuk bulan Agustus dan September 2019, $26.000 \mathrm{~kg}$ untuk bulan Oktober 2019, $24.000 \mathrm{~kg}$ untuk
JMTS| bulan November 2019, dan $26.000 \mathrm{~kg}$ untuk bulan Desember 2019.

2. Setelah di dapatkannya jumlah persediaan pupuk yang optimal dengan pemrograman dinamis, maka di dapatkan total biaya persediaan pupuk non-subsidi UD Barokah yang optimal adalah Rp.7.741.134.625 untuk tahun 2018-2019.

\section{REFERENSI}

[1] Hermawan, Christian, dkk. 2014. Pengoptimalan Persediaan Dengan Metode Simpleks. Saintia Matematika ISSN: 2337-9197 Vol. 2, No. 2 (2014), pp. 105-113. Medan.

[2] Hillier, Frederick and Gerald J. Lieberman. 2010. Introduction to Operations Research - ninth edition. The McGraw-Hill Companies. United States.

[3] Delfianda, Putri, Komalig, Hanny dan Manurung, Tohap. 2015. Optimalisasi Biaya Total Perencanaan dan Pengendalian Persediaan Menggunakan Program Dinamik (Studi Kasus : Nabila Bakery SPMA Kalasey Manado). JdC, Vol. 4, No. 1. Manado.

[4] Wardah, Siti dan Iskandar. 2016. Analisis Peramalan Penjualan Produk Keripik Pisang Kemasan Bungkus (Studi Kasus : Home Industry Arwana Food Tembilahan). Jurnal Teknik Industri, Vol. XI, No 3. Tembilahan.

\section{LAMPIRAN 1}

Persediaan dan Pembelian Bahan Baku Per-Periode

\begin{tabular}{|c|c|c|c|c|c|c|c|}
\hline $\begin{array}{c}\text { Bulan } \\
\text { ke- }\end{array}$ & $\begin{array}{c}\text { Jumlah } \\
\text { Perminta } \\
\text { an (Di) } \\
\text { (kg) }\end{array}$ & $\begin{array}{l}\text { jumlah xi+1 } \\
\text { yang mungkin } \\
\text { (lihat asumsi) }\end{array}$ & $\begin{array}{l}\text { Jumlah zi yang } \\
\text { mungkin (lihat } \\
\text { asumsi) }\end{array}$ & $\begin{array}{c}\text { Bulan } \\
\text { ke- }\end{array}$ & $\begin{array}{c}\text { Jumlah } \\
\text { Perminta } \\
\text { an (Di) } \\
\text { (kg) }\end{array}$ & $\begin{array}{l}\text { jumlah xi+1 } \\
\text { yang mungkin } \\
\text { (lihat asumsi) }\end{array}$ & $\begin{array}{c}\text { Jumlah zi } \\
\text { yang } \\
\text { mungkin } \\
\text { (lihat } \\
\text { asumsi) } \\
\end{array}$ \\
\hline 1 & 20825 & $\begin{array}{c}225<=x i+1<=22 . \\
225\end{array}$ & $\begin{array}{c}18.000<=\mathrm{zi}<=40 \\
.000\end{array}$ & 13 & 23182 & $\begin{array}{c}1000<=\mathrm{xi}+1<=17 \\
.000\end{array}$ & $\begin{array}{c}0<=z i<=40 . \\
000\end{array}$ \\
\hline 2 & 21021 & $\begin{array}{c}1200<=x i+1<=19 \\
.200\end{array}$ & $0<=z i<=40.000$ & 14 & 23379 & $\begin{array}{c}1600<=x i+1<=17 \\
.600\end{array}$ & $\begin{array}{c}0<=z i<=40 . \\
000\end{array}$ \\
\hline 3 & 21218 & $\begin{array}{c}0<=x i+1<=20.00 \\
0\end{array}$ & $0<=z i<=40.000$ & 15 & 23575 & $\begin{array}{c}25<=x i+1<=18.0 \\
25\end{array}$ & $\begin{array}{c}0<=z i<=40 . \\
000\end{array}$ \\
\hline 4 & 21414 & $\begin{array}{c}575<=x i+1<=18 \\
575\end{array}$ & $0<=z i<=40.000$ & 16 & 23772 & \begin{tabular}{|c|}
$250<=x i+1<=16$ \\
250 \\
\end{tabular} & $\begin{array}{c}0<=z \mathrm{zi}<=40 . \\
000\end{array}$ \\
\hline 5 & 21611 & $\begin{array}{c}950<=x i+1<=18 . \\
950\end{array}$ & $0<=z i<=40.000$ & 17 & 23968 & \begin{tabular}{|c|}
$275<=x i+1<=16$. \\
275
\end{tabular} & $\begin{array}{c}0<=z i<=40 . \\
000\end{array}$ \\
\hline 6 & 21807 & $\begin{array}{c}1125<=x i+1<=19 \\
.125\end{array}$ & $0<=z i<=40.000$ & 18 & 24165 & $\begin{array}{c}100<=x i+1<=18 \\
100 \\
\end{array}$ & $\begin{array}{c}0<=z i<=40 . \\
000\end{array}$ \\
\hline 7 & 22003 & $\begin{array}{c}1100<=x i+1<=19 \\
.100\end{array}$ & $0<=z i<=40.000$ & 19 & 24361 & $\begin{array}{c}1725<=\mathrm{xi}+1<=15 \\
.725\end{array}$ & $\begin{array}{c}0<=z i<=40 . \\
000\end{array}$ \\
\hline 8 & 22200 & $\begin{array}{c}900<=x i+1<=18 \\
900\end{array}$ & $0<=z i<=40.000$ & 20 & 4558 & $\begin{array}{c}1150<=x i+1<=17 \\
.150\end{array}$ & $\begin{array}{c}0<=\mathrm{zi}<=40 . \\
000\end{array}$ \\
\hline 9 & 22396 & $\begin{array}{c}500<=x i+1<=18 \\
500\end{array}$ & $0<=z i<=40.000$ & 21 & 24754 & \begin{tabular}{|c|}
$375<=x i+1<=16$ \\
375
\end{tabular} & $\begin{array}{c}0<=z i<=40 . \\
000\end{array}$ \\
\hline 10 & 22593 & $\begin{array}{c}0<=x i+1<=18.00 \\
0\end{array}$ & $0<=z i<=40.000$ & 22 & 24951 & $\begin{array}{c}1400<=x i+1<=15 \\
.400\end{array}$ & $\begin{array}{c}0<=z i<=40 . \\
000\end{array}$ \\
\hline 11 & 22789 & $\begin{array}{c}1200<=x i+1<=17 \\
.200\end{array}$ & $0<=z i<=40.000$ & 23 & 25147 & $\begin{array}{c}350<=x i+1<=16 \\
350\end{array}$ & $\begin{array}{c}0<=z i<=40 . \\
000\end{array}$ \\
\hline 12 & 22986 & $\begin{array}{c}200<=x i+1<=18 \\
200\end{array}$ & $0<=z i<=40.000$ & 24 & 25344 & $\begin{array}{c}1000<=x i+1<=15 \\
.000\end{array}$ & $\begin{array}{c}0<=\mathrm{zi}<=40 . \\
000\end{array}$ \\
\hline
\end{tabular}


LAMPIRAN 2

Hasil Perhitungan Tahap 1

\begin{tabular}{|c|c|c|c|c|c|c|c|c|c|c|c|c|c|c|c|}
\hline & \multicolumn{15}{|c|}{ TAHAP $1(n=1)$} \\
\hline & & \multicolumn{12}{|c|}{$f 1 \mid(2 x)=C(21)+h \times 2$} & \multirow{3}{*}{$f 1 \mid(x 2)^{*}$} & \multirow{3}{*}{$21^{*}$} \\
\hline \multirow{2}{*}{$x 2$} & \multirow{2}{*}{$h \times 2$} & $21=$ & $21=$ & $21=$ & $21=$ & $21=$ & $21=$ & $21=$ & $21=$ & $21=$ & $21=$ & $21=$ & $21=$ & & \\
\hline & & 18000 & 20000 & 2000 & 24000 & 26000 & 28000 & 30000 & 32000 & 34000 & 36000 & 38000 & 40000 & & \\
\hline 225 & 149.625 & 252.149.625 & & & & & & & & & & & & 252.149 .625 & 18000 \\
\hline 2225 & 1.479 .625 & & 281.479 .625 & & & & & & & & & & & 281.479.625 & 20000 \\
\hline 4225 & 2.809 .625 & & & 310.809 .625 & & & & & & & & & & 310.809 .625 & 22000 \\
\hline 6225 & 4.139 .625 & & & & 340.139 .625 & & & & & & & & & 340.139 .625 & 24000 \\
\hline 8225 & 5.469 .625 & & & & & 369.469 .625 & & & & & & & & 369.469 .625 & 26000 \\
\hline 10225 & 6.799 .625 & & & & & & 398.799.625 & & & & & & & 398.799 .625 & 28000 \\
\hline 12225 & 8.129 .625 & & & & & & & 428.129.625 & & & & & & 428.129.625 & 30000 \\
\hline 14225 & 9.459 .625 & & & & & & & & 457.459 .625 & & & & & 457.459.625 & 32000 \\
\hline 16225 & 10.789 .625 & & & & & & & & & 486.789 .625 & & & & 486.789 .625 & 34000 \\
\hline 18225 & 12.119 .625 & & & & & & & & & & \begin{tabular}{|l|l|}
516.119 .625 \\
\end{tabular} & & & 516.119 .625 & 36000 \\
\hline 20225 & 13.499.625 & & & & & & & & & & & 545.499 .625 & & 545.499 .625 & 38000 \\
\hline 22225 & 14.779 .625 & & & & & & & & & & & & 574.779 .625 & 574.779 .625 & 40000 \\
\hline
\end{tabular}

Hasil Perhitungan Tahap 2

\begin{tabular}{|c|c|c|c|c|c|c|c|c|c|c|c|c|c|c|c|c|c|c|c|c|c|c|c|c|}
\hline & & \multicolumn{21}{|c|}{  } & \multirow{3}{*}[2(2)3]{$^{*}$} & \multirow{3}{*}{$2^{*}$} \\
\hline \multirow{2}{*}{ B } & \multirow{2}{*}{ his } & $\eta=$ & il: & $l=$ & $i l=$ & $v=$ & $\imath=$ & $l=$ & $\eta=$ & ll: & $i l=$ & $\imath=$ & $\imath=$ & $i z=$ & il: & $\eta=$ & $\eta=$ & $i l=$ & $i=$ & $\eta=$ & $\imath=$ & $i l=$ & & \\
\hline & & 0 & 2000 & 4000 & 6000 & 8000 & 10000 & 12000 & 19000 & 15000 & 18000 & 20000 & 2000 & 24000 & 20000 & 20000 & 30000 & 3000 & 3000 & 3000 & 3000 & 4000 & & \\
\hline 1200 & 789000 & 57557.65 & 5424,255 & 52 2917.65 & 57158.65 & 50.257 .65 & 580927.65 & 506997.65 & 556.26 .65 & 54997.65 & 560.007 .65 & 56227.625 & 50997.65 & & & & & & & & & & 500947.65 & 2000 \\
\hline 3200 & 2128000 & 642137.25 & 69490.25 .55 & 60377.625 & 60249.62 & 600917.625 & \begin{tabular}{ll|l|}
599587.655 \\
\end{tabular} & 599.257.65 & 54927.65 & 595997.65 & 59966.65 & 522937.65 & 591607.65 & 59227.65 & & & & & & & & & 59027.65 & 2400 \\
\hline 5200 & 3458000 & 642897.65 & 663567.65 & 642137.65 & 62297.65 & 62157.62 .65 & 602.24 .7 .65 & 688917.65 & 627.59 .65 & 66267.65 & 624927.65 & 623597.65 & 62266.65 & 620937.65 & 69960.60 .65 & & & & & & & & 699.607 .65 & 2000 \\
\hline 7200 & 47880000 & 695557.65 & 69422.265 & 622997.65 & 62356.65 & 662.2736 .25 & 60.007 .65 & 69977.655 & 682.277 .65 & 666917.65 & 655.587 .65 & 65.157 .65 & 62297.65 & 651597.65 & 650.26 .625 & 648937.65 & & & & & & & 668.97 .25 & 2000 \\
\hline 9200 & 6.118000 & 762277.65 & 74288.255 & 723557.65 & 72227.65 & 692897.655 & 69956.65 & 69.27 .625 & 682907.65 & 68757.65 & 666.27 .65 & 624.97 .625 & 683587.65 & 682257.65 & 600927.65 & 699597.65 & 678.267 .65 & & & & & & 678266.625 & 3000 \\
\hline 11200 & 7448000 & 758877.65 & 755597.2.25 & 75:4217.65 & 72887.65 & 71557.625 & 722227.65 & 720997.65 & 79956.65 & 78837.65 & 766907.65 & 71557.625 & 714247.65 & 71291.65 & 711596.65 & 701057.65 & 708927.65 &  & & & & & 007597.65 & 32000 \\
\hline 13300 & 87780000 & 787537.65 & 766207.255 & 784.877 .65 & 783597.625 & 782217.65 & 700.88 .656 & 751557.65 & 750.227 .65 & 78489.65 & 774.566 .65 & 746.237 .65 & 74.97 .65 & 743577.65 & $742.27,625$ & 740.917 .65 & 739587.65 & $\begin{array}{ll}782.57 .655 \\
\end{array}$ & 736.927 .65 & & & & 786927.65 & 3000 \\
\hline 15000 & $10: 100000$ & 818197965 & 816867.25 & 815537.65 & 844207.65 & 812877.65 & 811579.65 & 80.277 .65 & 789887.65 & 79557.65 & 778.2726 .65 & 77689.656 & 775567.65 & 774237.65 & 772000.65 & 711577.65 & 770.274 .65 & 782997.65 & 766.587 .65 & 766267.65 & & & 776.57 .625 & 3000 \\
\hline 17200 & 11438000 & 899577.65 & 87722.265 & 84.197 .65 & 84.87 .65 & 8435.577.65 & 822070.65 & 84.877 .65 & 83957.7255 & 80.2717 .65 & 888887.65 & 80.57 .65 & 86227.65 & 804897.65 & 803365.65 & 802237.65 & 800.907 .65 & 79957.65 & 798.27 .765 & 786917.65 & 7755879.65 & & 755.57 .675 & 300 \\
\hline 192000 & 127858000 & 899517265 & 88887.25 & 876587.65 & 875257.62 & 84.979625 & 872867.65 & 87157.65 & 800.27 .625 & 88887.65 & 899577.625 & 8882717.65 & 85588.65 & 835575.65 & 834.427 .625 & 822897.65 & 881567.65 & 80027.765 & 88997.705 & 81757.65 & $82624,7.65$ & 82497.65 & 24497.725 & 4000 \\
\hline
\end{tabular}

